\title{
ФЕЙК — БРЕХНЯ В КОМУНІКАТИВНОМУ ПРОСТОРІ
}

\author{
ЛУКАШ МАЛЕЦКІ \\ Університет імені Адама Міцкевича, Познань - Польща \\ lmalecki@amu.edu.pl; ORCID: 0000-0002-5813-8630 \\ FEJK — KŁAMSTWO W PRZESTRZENI KOMUNIKACYJNEJ \\ ŁUKASZ MAŁECKI \\ Uniwersytet imienia Adama Mickiewicza, Poznań — Polska
}

STRESZCZENIE. Artykuł poświęcony jest problematyce tworzenia i rozpowszechniania fałszywych informacji (tzw. fejków) we współczesnej komunikacji masowej, szczególnie za pośrednictwem tzw. mediów społecznościowych. Podjęto próbę wskazania różnic pomiędzy fejkami, kłamstwem i manipulacją, a także przedstawiono klasyfikację różnych form fejków. W artykule zaproponowano również definicję "fejku" jako specjalnie skonstruowanego materiału (informacji lub wiadomości) zawierającego nieprawdziwe informacje oraz mającego na celu zwrócenie uwagi osób i przekonanie ich o prawdziwości przedstawionych danych.

Słowa kluczowe: fejk, kłamstwo, informacja, komunikacja masowa, manipulacja.

\section{FAKE NEWS — LIE IN COMMUNICATIVE SPACE \\ LUKASZ MALECKI \\ Adam Mickiewicz University, Poznan — Poland}

ABSTRACT. The article describes the creation and distribution of fake information (also called as fakes) in nowadays mass communication, especially in social media and social networks. The differences between fake news, lying, manipulation have been described; the classification of different forms of fake has been suggested. In the article the definition of "fake" has been proposed as a specially created material (information or news) that contains untruthful information to which applies specifically to mislead people and to convince them of the veracity of the presented news.

Keywords: fake, lie, information, mass-communication, manipulation.

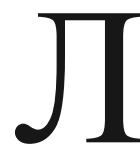

юдське життя розгортається як постійна взаємодія між окремими індивідами або індивідом і групою, до якої він належить. Їхні інтереси, намагання, прагнення, очікування не завжди бувають спільними - можуть бути й різними, навіть протилежними й суперечливими, можуть коливатися від довіри до недовіри, від взаємопорозуміння до конфлікту, що, безперечно, має своє специфічне віддзеркалення в повсякденній комунікації. За своєю природою людина - соціальна багато- і різнофункціональна істота, але незалежно від функцій, які вона виконує в суспільстві загалом або в окремій суспільній групі, людина завжди є або відправником (комунікатором) певного повідомлення (актуальних відомостей, фактів, аргументів, ідей, думок, роздумів, емоційно забарвленої інформації і т. д.), або його одержувачем.

Комунікація - інтеракція, двосторонній зв'язок, взаємодія співрозмовників. Кожен вид комунікації відрізняється один від одного не тільки специфічним характером комунікативного процесу, а й природою тих компонентів, які організовують процес спілкування. Окрім того, кожний з учасників комуніка- 
ції має також власні уявлення про предмет обговорення, індивідуальну картину світу.

Не викликає жодних сумнівів теза, що комунікація - один із центральних складників існування і функціонування сучасного суспільства. На початку XXI ст. вона стала свідком і безпосереднім учасником комунікативної революції, пов'язаної з виникненням, а також потужним розширенням і розповсюдженням інформаційних технологій. Комунікація набула нового характеру - невід’ємною iї частиною стала прикмета “масова”. Природа масової комунікації - у виробництві та розповсюдженні, поширенні інформації за допомогою технічних засобів, що впливають на чисельно великі групи населення.

У соціології масову комунікацію описують у термінах соціального спілкування, соціального обміну або соціальної взаємодії. Спільним у вищеназваних описах є те, що йдеться про символічні форми взаємозв'язку в суспільстві, тобто такі, що репрезентують у соціумі відповідні знання, духовні цінності, моральні, етичні, правові норми - письмові та аудіовізуальні тексти ${ }^{1}$.

Масова комунікація з'явилася порівняно недавно, але за короткий час вона набула такого поширення в усіх галузях людського існування, що тепер практично неможливо уявити собі існування будь-якого суспільства без інформації та джерел іiі розповсюдження насамперед за допомогою електронних засобів.

Масовість як визначальна характеристика комунікації створює нові сутності в комунікаційному процесі. Учасниками процесу спілкування вважаються вже не окремі індивіди, а збірні (у певному сенсі абстрактні) суб'єкти: соціальні, територіальні, етнічні групи, об’єднання, народи та ін. Сучасні дослідники доходять висновку про те, що, ураховучи саме цей фактор, функція інформування в масовій комунікації поступається місцем функції об'єднання, а слідом за нею - управління, підтримання соціального статусу, підпорядкування і влада ${ }^{2}$.

Значною мірою саме масова комунікація забезпечує цілісність людської спільноти. Функція масової комунікації щодо підтримання загального й універсального зв'язку між людьми, державами й культурами настільки важлива, що дає підстави для уявлень про “інформаційну” цивілізацію. Мабуть, саме тому сучасне суспільство визначається як “інформаційне”, або “суспільство massmedia".

3 появою й потужним розповсюдженням електронних засобів передавання інформації людство поступово перейшло в культуру диференційованого, фрагментованого сприйняття реальності, тобто створення картини світу з окремих шматків інформації. Підтвердженням цієї тези є, напр., поширення таких комунікатів у соціальних мережах, які тепер посідають суттєву частину нашого життя, поєднують як міжперсональну, так і масову комунікацію.

У соціальних мережах поряд 3 новинами інформаційних агентств простежуємо й повідомлення про особисте життя користувачів Інтернету, їхніх друзів, членів сім'ї тощо. Більше того, навіть про новини зі ЗМІ можна дізнаватися за допомогою інших інтернет-користувачів, які їх поширюють. Або ж, навпаки, повідомлення користувача може стати новиною, яку публікують інформаційні агентства. Складно знайти середовище, у якому межі між публічним та персональним були б більше розмитими.

${ }^{1}$ А. 3. Москаленко, Л. В. Губерський, В. Ф. Іванов, Масова комунікаиія, Київ 1997, c. $75-78$.

${ }^{2}$ Там само, с. 84. 
Усесвітня мережа нині стала основним постачальником інформації, а кількість іï користувачів швидкими темпами зростає. Нові технології, легкість доступу до Інтернету, популярність соціальних мереж, що постійно зростає, щораз швидша комунікація й практично необмежені можливості чи не для кожної людини долучатися до творення повідомлень активно сприяють поширюванню потоку фальшивої інформації, неправдивих новин, які прийнято називати фейками.

Мета цієї статті - спроба визначити поняття фейк, що є суттєвим складником сучасного комінукативного простору.

Хоча термін фейк активно функціонує майже в усіх медійних сферах і привертає зацікавлення соціуму, але комплексні наукові дослідження цього порівняно нового феномена практично відсутні. Саме цей факт мотивує потребу подібного аналізу.

Масова комунікація реалізується на двох рівнях: когнітивному й інтерактивному, що невід’ємно пов'язані з процесами поширення інформації серед населення. Тому слово “інформація” можна інтерпретувати як “ознайомлення”.

Соціальні за змістом дані й відомості, розповсюджені за допомогою різних комунікаційних каналів, створюють інформаційну основу для когнітивної діяльності соціальних суб'єктів. Занурюючись у масову комунікацію, вони здатні використовувати отриману інформацію як пізнавальний ресурс у процесі формування своїх уявлень, думок, ціннісних орієнтацій. На цьому рівні образи як окремих індивидів, так і суспільства перетворюються на стихійно або випадково сформовані копії наукової чи культурної картини світу. Проте вони можуть бути навмисне деформованими, недостовірними відбитками реальних процесів ${ }^{3}$.

У системі мас-медійного (передусім інтернетівського) спілкування містяться великі технічні можливості, але зовсім відсутні засоби контролю за інформацією й стримування відправників. Отже, інтернетівська система спілкування має характер соціально й психологічно незахищеної системи, у якій неодноразово порушуються рівновага (а) правильного й неправильного, (б) морального й аморального, (в) етичного й неетичного і т. д. Постійне порушення такої рівноваги стає підгрунтям для породження й розповсюдження фейків.

Фейк - багатозначне слово іншомовного походження (від англійського $f a$ $k e)^{4}$. У найширшому розумінні - це підробка, вигадка, фальсифікація, які хтось намагається видати за оригінал. Це слово спершу застосовували як назву для підробок відомих світових брендів, напр.:

- „Китайський «фейк» підкорює світ. Підробки всюди: дзвонять з кишень бідних студентів, покояться в косметичках модниць на дні їх «брендових» сумочок і навіть заповнюють полиці дитячих магазинів".

- „Виробникам оригінального взуття та одягу постійно доводиться судитися з фірмами-виробниками підробленої одягу. В основному фейки поставляють з Китаю, Індонезії, Туреччини та інших країн Східної Свропи та Східної Азіï"'6.

- „На урочистому вечорі Вікторія Бекхем з'явилася з підробленою сумкою

${ }^{3}$ О. В. Зернецька, Глобальний розвиток систем масової комунікації $і$ міжнародні відносини, Київ 1999, с. $150-155$.

${ }^{4}$ English Oxford Living Dictionaries, [в:] Електронний ресурс: https://en.oxforddictionaries. $\mathrm{com} /$ word-of-the-year/word-of-the-year-2016 (10.11.2017).

${ }^{5}$ Пластиковий китайський рис: розпізнаємо підробку, [в:] Електронний ресурс: www.vikna. if.ua (01.05.2018).

${ }_{6}^{6}$ Як відрізнити бренд від підробки в одязі, [в:] Електронний ресурс: www.altarta.com (08.01.2018). 
Louis Vuitton. Креативний директор бренду Марк Джейкобс, помітивши фейк в руках зірки, відправив їй справжню сумку LV із запискою: "Дорога, тримаєте марку!» Вікторія відразу поспішила виправдатися: сумку їй подарували шанувальники (...)"”.

3 поширенням соціальних мереж поняття фейк почали застосовувати для означення несправжніх акаунтів, сайтів, а з початком активної фази так званої інформаційної війни це поняття все активніше використовують для назви неправдивої інформації або неправдивих фотографій і відеофільмів, що ії супроводжують, напр.:

- , ,...] деякі держсавні 3МI перетворилися на пропагандистські машини для поширення фейковий новин і розпалювання ненависті та ксенофобї”".

- „У сучасних умовах, коли ведеться справжня війна на інформаційному фронті, війна без правил $і$ без моральних обмежень, чи не найбільш підступною i небезпечною зброєю масового ураження людських мізків вважають фейк”".

- ,,[...] в мережі постійно створюються фейкові аккаунти, брендовані логотипом Ukraine Today, через які поширюється антиукраїнська пропаганда. У нас були прецеденти створення фейкових сторінок на Facebook ma Youtube, через які поширювався відверто антиукраӥнський контент. Їх важко візуально відрізнити, оскільки вони брендовані логотипом каналу"'10.

- ,Служба безпеки України виявила в Інтернеті фейковий веб-ресурс, який за своїм виглядом та наповненням повністю копіює інтернет-портал СБУ"'Il.

- „Ця фейкова постанова є иинічним проявом агресивної пропаганди, яка з усією очевидністю спрямована проти України, ї̈ міжнародного іміджу та

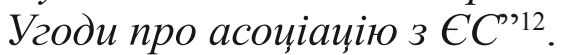

Поряд із часто вживаними виразами фейкова сторінка, фейковий аккаунт, фейковий сайт можна почути й вираз фейкові продукти та все частіше кові новини, альтернативні факти, а також словосполучення фейкові вибори (на Донбасі), фейкова партія, фейкові кандидати, фейковий президент, фейкова краӥна (або краӥна-фейк) і т. д.

Найбільш загрозливий вид фейку - неправдива інформація, що миттєво поширюється в 3МІ. Звичайно, фейки, тобто фальшиві, вигадані новини, супроводжували комунікацію впродовж усієї іiі історії, але спочатку їх, зокрема в журналістиці, назвали “газетними качками”, або просто чутками, плітками й на широке розповсюдження в Інтернеті вони найчастіше не мали впливу.

Тривалий час вищеназвані чутки, або “газетні качки”, були нешкідливими. Найчастіше це була свідома дія редакції для залучення до свого видання (найчастіше друкованого) уваги широкої публіки, підвищення його продавання, зростання популярності.

Однак все змінилося разом з появою Інтернету та його унікальною здатністю швидко й багаторазово розповсюджувати новини, щоб тільки привернути загальну увагу. Сьогодні на зміну старій і нешкідливій “газетній качці” з'явилося поняття “фейк”, мета якого вже зовсім інша.

Терміни “фейк” і “фейкові новини” трактують як повністю або частково вигадану інформацію про суспільні події, явища, певних осіб, що подається

\footnotetext{
${ }^{7}$ Там само.

${ }^{8}$ Газета „Сегодня”, [в:] Електронний ресурс: https://ukr.segodnya.ua (25.04.2018).

${ }^{9}$ Газета „День”, [в:] Електронний ресурс: https://day.kyiv.ua (30.05.2015).

${ }^{10}$ Там само (30.05.2014).

${ }^{11}$ Там само (29.10.2015).

${ }^{12}$ Там само (19.01.2016).
} 
під виглядом справжніх журналістських матеріалів. Найсприятливішим місцем для поширення такої “зараженої” інформації $є$ Інтернет, а точніше - соціальні мережі. Це зумовлено тим, що величезний потік інформації не фільтрується ані модераторами соціальних спільнот, ані споживачами цієї інформації. Окрім того, звичайні користувачі, які не мають відповідних навиків роботи з отримуваними повідомленнями, загалом перестають відрізняти достовірну інформацію від вигаданої, правду від брехні. В інформаційному потоці стає важко помітити, де фейк, а де достовірна інформація.

Інформація здатна іноді надовго затримуватись у когнітивних шарах колективної або індивідуальної свідомості. Однак у разі критичного осмислення чи некритичного сприйняття іiі під впливом цілеспрямованої пропаганди вона може зростатися із системою цінностей і норм різних груп і категорій індивідів і включатися в регуляцію їхніх контактів із середовищем. Отримавши інформацію, індивід (або група) співвідносить себе з конкретним середовищем, етнічною спільнотою, політичним рухом, тобто здійснює соціальну й ціннісну ідентифікацію. За допомогою каналів масової комунікації поступово формується громадська думка, настрої, емоції, поведінка.

Як було зазначено, слово фейк використовується в інформаційній сфері для позначення сфабрикованого, фальшивого повідомлення. Можна виділити три основні причини, що сприяють розповсюдженню фейків: (1) поступальні зміни в спілкуванні та комунікаційних технологіях, (2) політична невизначеність, (3) збройні конфлікти.

Фейки, як і плітки або чутки, виникають там, де $\epsilon$ інформаційний вакуум. Людина як істота допитлива i творча, постійно шукає пояснення того, що іiі хвилює, що їй не зрозуміло. Коли суспільство не пропонує готових рецептів, немає фактів і коментарів авторитетних джерел, то аудиторія починає творити необхідний їй контент самостійно. Дезінформація, фейки це високоорганізований механізм поширення чуток на великі аудиторії. Зазвичай такі повідомлення відповідають очікуванням або страхам, озвучують те, що люди самі не наважуються першими сказати вголос ${ }^{13}$. Однак фейк дещо відрізняється від плітки. Плітки корегують соціальну поведінку і несуть у собі психотерапевтичний ефект. Вони завжди мають означені межі, які не слід перетинати. „Плітка - це пастух, який пасе свою отару”14. Плітки найчастіше містять певні факти або припущення стосовно людей. Фейки необов'язково стосуються людей, вони можуть торкатися політичних і соціальних явищ.

За словами Г. Почепцова, „фейк, як і свого часу чутка, побудований так, щоб задовольняти інтереси й очікування читача, бо тільки так він має шанс поширитися. Не поширюватиметься й те, у чому немає відтінку новизни, адже фейк — це новина"15.

Фейк часто ототожнюють з брехнею, обманом. Американський психолог П. Екман визначає обман як дію, якою одна людина вводить в оману іншу, робить це навмисно, без попереднього повідомлення про свою мету та без чітко вираженого з боку адресата прохання не повідомляти правду. ${ }^{16}$ У певних ситуаціях, на думку цього дослідника, брехун обманює протягом усього процесу ко-

${ }^{13}$ I. Р. Алтунина, Социальная психология, Москва 2011, с. 127-129.

${ }^{14}$ О. Т. Баришполець, Брехня в інформачійному просторі та міжособовій комунікаиії, Кіровоград 2013, с. 315.

${ }^{15}$ Г. Почепцов, Як у наші двері постукали... фейки, [в:] Електронний ресурс: https://dt.ua/ SOCIUM/yak-u-nashi-dveri-postukali-feyki-267362_html (20.04.2018).

${ }^{16}$ П. Екман, Психологія обману. Обмани мене, якщо зможеш, СПб 2018, с. 22. 
мунікації, в інших - удається до брехні як до тимчасової “маски”, що приховує вчинки, думки та ін.

П. Скман уважає, що обман не має виправдання, людина завжди сама свідомо обирає, чи вдаватися до нього, у більшості випадків чітко розуміючи відмінність між правдою й обманом. Фейк, як і обман, створюється свідомим бажанням адресанта надати адресату певну інформацію, що не відповідає дійсності. Обман, як і фейк, може подаватися у вигляді інформації, з якої опоненту пропонується самостійно зробити помилкові висновки, і тоді він стає співучасником обману, жертвою власних думок. Фейк, як і обман, брехня, може виглядати як правда, що подається таким чином, що в неї важко повірити.

I брехня, і фейк - це способи спотворення, тобто обману. Визначальним елементом брехні $є$ іiі неістинність. Саме тому брехуном називають насамперед того, хто вголос говорить неправду. На відміну від брехні, фейк пов'язаний не тільки 3 неправдою, а й з удаванням, тобто можна вважати, що саме цей фактор - удавання, прикидання - специфічна ознака фейків.

Фейкова інформація містить реальні й вигадані факти, подані в такому співвідношенні, щоб спровокувати співрозмовника на помилкові висновки й хибні, але вигідні для комуніканта вчинки.

Мета брехуна, тобто “фейкотворця”, за допомогою всіх можливих засобів комунікації дезінформувати адресата та ввести його в оману. Адже фейк не тільки підробка, фальшивка, але також сам процес - негативна інформація, що не відповідає дійсності, яка швидко розповсюджується для того, щоб дезінформувати аудиторію.

Однією з причин, через які брехня і фейки мають переваги над правдою, $€$ їхня "свіжість”. Фейкові новини часто неймовірні, тому люди їх “купують": їх цікавить нове, нестандартне, нетипове, а не банальна, зрозуміла й нудна правда. Фейкові новини можуть бути ефективними тільки тоді, коли вони вкладаються в певну “картину” світу.

Підтвердженням цього є твердження, надруковане в американському журналі The Guardian, де зазначено, що „фейки розширюють межі того, у що ми віримо. I тим не менше, люди думають, що це правда. [...] Це не означає, що читачі дурні або надто довірливі: це означає, що формат новин легко імітувати, а деякі реальні новини досить дивовижні й викликають недовіру"17.

Люди, які перебувають у певній системі координат, понять, традицій, сприймають світ відповідним чином. Ця система $є$ предметом віри: довести іï емпіричним шляхом практично неможливо. Частина аудиторії вірить у те, що не існує, та має викривлене розуміння сучасної картини світу.

Ефективність фейків передусім пояснюють їхньою здатністю ставати правдоподібними. Ці повідомлення фальшиві, але, грунтуючись на поширених у суспільстві стереотипах, симпатіях й антипатіях, а також використовуючи легко й миттєво розпалювані емоції, зокрема такі, як страх, паніка, фрустрація, гнів, вони можуть привернути увагу адресатів. Отже, зміст фейку, навіть безпідставний, набуває такої видимості правди, що навіть авторитетні спростування навряд чи можуть їм зашкодити.

На фейки можна було б не звертати уваги, сприймати їх як байки чи гуморески, якби такі повідомлення не були інформаційною зброєю масового ураження.

17 ”The Guardian”, [в:]: Електронний pecypc: https://www.theguardian.com/technology/2017/ jul/26/fake-news-obama-video-trump-face2face-doctored-content (22.05.2018). 
Фейки часто стають вірусними, тобто поширюються швидко та нестримно, керуючись не стільки характерною для соцмереж логікою обміну, скільки захопленням ненаситною жагою, яку легко розпалити в людині.

Фейк як явище сучасного інформаційного суспільства останнім часом потрапив у фокус зацікавлення не тільки науковців, але й суспільства загалом, через сукупність різних чинників, передусім у зв'язку з президентською кампанією в США. Дослідження цього нового виду медійної брехні пов'язане також із війною на сході України - війною не тільки в мілітарному вимірі, але також інформаційному ${ }^{18}$.

Фейки - один з найбільш часто використовуваних інструментів в інформаційній війні. У цьому разі йдеться не про фальшиві сторінки знаменитостей у соцмережах чи підроблені сайти. Набагато більшу небезпеку сьогодні становить поширення завідомо неправдивої інформації, що наводнює Інтернет, а потім підхоплюється іншими 3МI, і здатна сіяти паніку, породжувати агресію, нерозуміння, посилюючи негативні процеси в суспільстві загалом.

Основна мета фейкових повідомлень як інструмента інформаційної війни - це посіяти сумніви й переконати аудиторію в правдивості поданої інформації, пропагувати власне бачення, політику чи позицію; викликати агресію; змінити усталену думку; переконати аудиторію за допомогою вигаданих фактів щодо певної дії і т. д.

Фейки пов'язують 3 дезінформацією, поширюваною в Інтернеті або в традиційних медіа. Дезінформація - це спосіб психологічного впливу, що полягає в поданні споживачеві такої інформації, яка вводить його в оману та створює викривлену реальність. Це поширення перекручених, неповних або свідомо неправдивих відомостей для досягнення пропагандистських, військових (введення противника в оману), комерційних або інших цілей.

До розпалу українсько-російського конфлікту українські ЗМІ та реципієнти часто сприймали фейк як жарт - навмисне перекручення фактів, аби викликати позитивні емоції, сміх тощо. Однак тепер дедалі частіше фейк перетворюється на справжню дезінформацію, що вводить в оману. У рамках так званої інформаційної війни фейки поширюються передусім із пропагандистською метою, зокрема для створення однозначного образу ворога, для спрощення світу, порівн.: ,, Оскільки ми живемо в інформаційному світі, наше бачення та реакції визначаються змістом інформації, яку ми споживаємо. Із огляду на це, поширення фейкових повідомлень не може не позначитися на психічному здоров' $i$ суспільства. [...] Люди вважають найбільш важливими саме ті теми й проблеми, які активно висвітлюються й обговорюються в ЗМІ. Таким чином можна цілеспрямовано коригувати - тобто манупулювати - уявлення суспільства - фактично формувати нову реальність"

Труднощі щодо виявлення й викорінення фейків виникають і через те, що люди часто взаємодіють у межах однорідних і непроникних для інших точок зору й думок. Результат логіки цієї дезінформації - замість здорової конфронтації 3 іншими джерелами інформації, що дозволило 6 позитивно засумніватися й відкрити конструктивний діалог, ми ризикуємо стати мимовільними учасниками поширення упереджених і безпідставних думок. Мета дезінформації полягає в дискредитації іншого, презентації його як ворога

${ }^{18}$ Г. Почепцов, Сучасні інформаційні війни, Київ 2015.

${ }^{19}$ П. Фролов, Фейк як інструмент війни, [в:] Електронний ресурс: https://ay.kyiv.ua/uk/ article/media/feyk-yak-instrument-viyni (22.05.2018). 
— аж до демонізації, що може розпалювати конфлікти. Отже, фальшива інформація демонструє наявність одночасно деструктивних і загрозливих настанов, єдиним наслідком чого є можливість поширення нетолерантності та ненависті.

Поширення фейків може базуватися на маніпулятивному використанні соцмереж. У сучасній літературі термін “маніпулювання” вживається на позначення вміння керувати поведінкою людини за допомогою цілеспрямованого впливу на суспільну психологію, свідомість та інстинкти людини; ідеологічна дія для зміни поведінки людей ${ }^{20}$.

Під час маніпуляційного мовленнєвого акту ключовим моментом для адресата $є$ приховування фактичних намірів, мотивів, цілей, намагання зробити так, щоб реципієнт навіть не здогадувався про них. Маніпуляція зазвичай ототожнюється з обманом. С. Кара-Мурза розглядає обман як один з важливих прийомів у технології маніпуляції. Він зазначає, що обман - це маніпуляція переконання, оскільки є спробою переконати адресата в правдивості пропозиції, у яку сам адресант не вірить ${ }^{21}$. Услід за поясненням правдивості тези Дж. Лакоффа і М. Джонсона — "we understand a sentence as being true when our understanding of the sentence fits our understanding of the situation closely enough"22 — розумісмо висловлення як неправдиве, якщо наше розуміння висловлення не відповідає нашому розумінню ситуації.

Маніпулювання громадською думкою шляхом створення фейків активізує не що інше, як одну з найбільших людських слабкостей — лінь. Фейки легкодоступні: вони самі “йдуть до рук”, на їхні пошуки, на відміну від якісної інформації, не треба витрачати часу й інтелектуальних зусиль ${ }^{23}$.

Часто фейк трактують як синонім до поняття "неправдива інформація". Адже фейк передбачає навмисне перекручення, вигадування, дезінформування, а неправдива інформація може бути подана у ЗМІ випадково - через халатність журналістів, неуважність, недостатню перевірку інформації. Неправдива інформація може бути спростована засобом масової інформації, у яких вона була подана, а отже, дезінформаційний вплив на аудиторію буде не таким вагомим. Тому, на нашу думку, фейк є видом неправдивої, викривленої інформації, а не їі повним ототожненням.

Класифікувати фейкову інформацію можна за різними ознаками, напр. за:

- формою подання (текст, фото, відео);

- змістом (агітація, пропаганда, маніпуляція тощо);

- тематикою (найчастіше політичні, соціальні, рідше - світські);

- призначенням для певної вікової категорії;

- джерелом інформації (без джерела, невідоме джерело і т. д.).

3 огляду на висловлене, пропонуємо таке визначення поняття фейк: спеціально створена та оприлюднена неправдива, навмисно викривлена інформація, що миттсво поширюсться в процесі масової комунікації з метою дезінформування, маніпулювання суспільною свідомістю і думкою, моделювання певних ситуацій і заздалегідь передбачених реакції на них.

Значення засобів масової інформації - друку, радіо, телебачення, Інтернету - у житті сучасної людини важко переоцінити, адже, зважаючи на суспільну важливість, масовість та доступність, мас-медіа перетворилися на потужний

${ }^{20}$ Т. С. Дорошенко, Великий комплексний словник украӥнської мови, Харків 2009, с. 520.

${ }^{21}$ С. Г. Кара-Мурза, Манипуляиия сознанием, Москва 2007, с. 560-562.

${ }^{22}$ Дж. Лакофф, М. Джонсон, Метафоры, которыми мы живём, Москва 1990, с. 169.

${ }^{23}$ Е. Л. Доценко, Психология манипуляиии: феномены, механизмы и защита, Москва 1997, c. 244. 
інструмент-регулятор, що формує суспільну думку та впливає на настрої більшої частини населення.

В епоху розвитку інформаційних технологій у XXI ст., в умовах безупинного спілкування суспільства в соціальних мережах, розповсюдження брехливих новин саме фейк стає одним зі складників медіапростору та сегментом соціальних мереж.

Епоха фейку, на думку Г. Почепцова, приходить разом із соціальними медіа, коли різко зросли обсяги інформації, яку отримує кожна конкретна людина. I справа навіть не в обсягах, а в зміні парадигми породження й отримання інформації. Соціальні медіа, соціальні мережі спрощено поляризують сприйняття світу. Це спрощення небезпечне, оскільки інтернет-ресурси поділяються на достовірні та недостовірні. I якщо не усвідомити цієї межі, то є ризик читати лише “погані” джерела інформації незалежно від країни, де вони поширюються.

Перспективним уважаємо дослідження характерних ознак фейкових текстів (комунікатів) з урахуванням специфіки сайтів, на яких розміщені ці “новини”.

\section{Список використаної літератури}

Алтунина I. Р., Социальная психология, Москва 2011.

Баришполець О. Т., Брехня в інформаційному просторі та міжособовій комунікацї̈, Кіровоград 2013.

Газета „День”, [в:] Електронний ресурс: https://day.kyiv.ua.

Газета „Сегодня”, [в:] Електронний ресурс: https://ukr.segodnya.ua.

Дорошенко Т. С., Великий комплексний словник української мови, Харків 2009.

Доценко Е. Л., Психология манипулячии: феномены, механизмы и защита, Москва 1997.

Екман П., Психологія обману. Обмани мене, якщз зможеш, СПб 2018.

Зернецька О. В., Глобальний розвиток систем масової комунікації і міжнародні відносини, Київ 1999.

Кара-Мурза С. Г., Манипулячия сознанием, Москва 2007.

Лакофф Дж., Джонсон М., Метафоры, которыми мы живём, Москва 1990.

Москаленко А. З., Губерський Л. В., Іванов В. Ф., Масова комунікачія, Київ 1997.

Пластиковий китайський рис: розпізнаємо підробку, [в:] Електронний ресурс: www. vikna.if.ua (01.05.2018).

Почепцов Г., Сучасні інформачійні війни, Київ 2015.

Почепцов Г., Як у наші двері постукали... фейки, [в:] Електронний ресурс: https://dt.ua/ SOCIUM/yak-u-nashi-dveri-postukali-feyki-267362_html (10.01.2018).

Фролов П., Фейк як інструмент війни, [в:] Електронний ресурс: https://day.kyiv.ua/uk/ article/media/feyk-yak-instrument-viyni (22.05.2018).

Як відрізнити бренд від підробки в одязі, [в:] Електронний ресурс: www.altarta.com (08.01.2018).

English Oxford Living Dictionaries, [в:] Електронний ресурс: https://en.oxforddictionaries. com/word-of-the-year/word-of-the-year-2016 (10.11.2017).

"The Guardian", [в:] Електронний ресурс: https:/www.theguardian.com/technology /2017/ jul/26/fake-news-obama-video-trump-face2face-doctored-content (22.05.2018).

\section{Spysok vykorystanoi literatury [References]}

Altunina I. R., Socialnaya psihologiya [Social Psychology], Moskva 2011.

Baryshpolets O. T., Brekhnia v informatsiinomu prostori ta mizhosobovii komunfkatsii [Lie in Informational Space and Interpersonal Communication], Kirovohrad 2013.

Hazeta „Den” [“Day”], [v:] Elektronnyi resurs: https://day.kyiv.ua. 
Hazeta „Sehodnia” [“Today”], [v:] Elektronnyi resurs: https://ukr.segodnya.ua.

Docenko E. L., Psihologiya manipulyacii: fenomeny, mehanizmy i zashita [Psychology of Manipulation: Phenomena, Mechanisms and Defence], Moskva 1997.

Doroshenko T. S., Velykyi kompleksnyi slovnyk ukrainskoi movy [Big Complex Dictionary of the Ukrainian Language], Kharkiv 2009.

Ekman P., Psykholohiia obmanu. Obmany mene, yakshcho zmozhesh [Psychology of Lie], $\mathrm{SPb} 2018$.

Zernetska O. V., Hlobalnyi rozvytok system masovoi komunikatsii i mizhnarodni vidnosyny [Global Development of Mass Communication Systems and International Relations], Kyiv 1999.

Kara-Murza S. G., Manipulyaciya soznaniem [Manipulation of Consciouness], Moskva 2007.

Lakoff Dzh., Dzhonson M., Metafory, kotorymi my zhivyom [Metaphors we Live by], Moskva 1990.

Moskalenko A. Z., Huberskyi L. V., Ivanov V. F., Masova komunikatsiia [Mass Communication], Kyiv 1997.

Plastykovyi kytaiskyi rys: rozpiznaiemo pidrobku [Plastic Chinese Rice: Fake Detection], [v:] Elektronnyi resurs: www.vikna.if.ua (01.05.2018).

Pocheptsov H., Suchasni informatsiini viiny [Modern Information War], Kyiv 2015.

Pocheptsov H., Yak u nashi dveri postukaly... feiky [The Way Fake Knocked on our Door], [v:] Elektronnyi resurs: https://dt.ua/SOCIUM/yak-u-nashi-dveri-postukali-feyki-267362_. html (10.01.2018).

Frolov P., Feik yak instrument viiny [Fake as Instrument of War], [v:] Elektronnyi resurs: https://day.kyiv.ua/uk/article/media/feyk-yak-instrument-viyni (22.05.2018).

Yak vidriznyty brend vid pidrobky v odiazi [How to Detect Brand from Fake], [v:] Elektronnyi resurs: www.altarta.com (08.01.2018).

English Oxford Living Dictionaries, [v:] Electronic resource: https://en.oxforddictionaries. com/word-of-the-year/word-of-the-year-2016 (10.11.2017).

"The Guardian", [v:] Electronic resource: https://www.theguardian.com/technology/ 2017/ jul/26/fake-news-obama-video-trump-face2face-doctored-content (22.05.2018). 